\title{
Study on the Development Models of Pro-poor Tourism in Jilin Province
}

\author{
Chunyan Wang
}

College of Business Administration, Jilin Engineering Normal University, Changchun, China

541012329@qq.com

\author{
Keywords: Pro-poor tourism (PPT); Development model; Existing problems; Research; Jilin \\ province
}

\begin{abstract}
Pro-poor tourism as a strategic tool aims at alleviating the poverty of poor groups in poor areas. There are so abundant eco-tourism resources in Jilin province, but at the same time some state-level poverty-stricken counties are located in the enrichment area of these tourism resources. In this paper, it analyzes the status of the poor population distribution and the development of pro-poor tourism in Jilin province, further dissects the existence problems in development of pro-poor tourism in Jilin Province, and puts forward some development models of pro-poor tourism for promoting the development of Jilin Province, such as the independent development model of local interest community, the leading model by enterprises, the driven model of policy project and so on.
\end{abstract}

\section{Introduction}

Anti-poverty has always been an important issue for all mankind. Countries around the world have been working to excavate the potential of tourism in poverty alleviation. Tourism is directly linked to anti-poverty, becoming a new topic in recent years. Taking into account the coincidence of the spatial distribution between the enrichment area of tourism resource and the gathering area of poor people, developing tourism has become an important measure and strategy for anti-poverty. Many countries and regions by virtue of their rich tourism resources, vigorously develop the tourism industry, pro-poor tourism has achieved great success in practice. The poverty alleviation effect caused by tourism has aroused widespread concern in academic circles at home and abroad.

\section{Literature Review on the Concept of Pro-poor Tourism}

From all the collected concepts of pro-poor tourism, the academic understanding of pro-poor tourism has not yet reached a unified. A more representative definition of tourism pro-poor tourism is the PPT (Pro-poor Tourism), which was developed in 1999 by UK Department for International Development (DFID) [1]. Another is the ST-EP (Sustainable Tourism and Eliminating Poverty), which is proposed by World Tourism Organization in 2002 [2]. Pro-poor tourism (PPT) is a kind of tourism development mode which can promote to reduce poverty, that the net benefit to the poor from tourism development [3]. Some scholars believe that the concept of PPT alienated the relationship between tourism managers, investors, tourists and other related interest groups [4]. Therefore, they prefer to use ST-EP instead of PPT. The core of ST-EP is the sustainable tourism as a means of poverty reduction, to solve some social, cultural, environmental and other negative issues in the development of tourism.

With the development of pro-poor tourism practice in China, the concept of pro-poor tourism was first proposed in 1991. So far, domestic scholars have defined the concepts of pro-poor tourism as many as dozens, but have not yet formed a unified definition. From the many definitions, we can sum up the common understanding of the concept of pro-poor tourism among domestic scholars: the development of pro-poor tourism needs certain precondition, is generally implemented in the poverty-stricken areas (or underdeveloped areas) with certain tourism development conditions and basis [5]; pro-poor tourism is a kind of "hematopoietic" poverty alleviation, which is different from the previous way of poverty alleviation [6]; pro-poor tourism cannot develop without the prerequisite of tourism development, that means tourism development is the foundation of pro-poor tourism [7]; poverty alleviation is the essence of pro-poor tourism, and tourism development is only the way and means to develop the pro-poor 
tourism [8]; the object of pro-poor tourism is to achieve the economic development in poor areas or to help overcome the poverty by developing tourism [9], etc..

\section{Current Development and Existing Problems of Pro-poor Tourism in Jilin Province}

Distribution Status of Poverty Population in Jilin Province. Since 2000, in accordance with Chinese poverty standards, about 2000 poverty villages are selected from 10107 administrative villages in Jilin province, covering a total population of nearly 1.2 million people. In 2002, 8 poverty-stricken counties (cities) were indentified as the national key support counties including Jingyu, Tongyu, Zhenlai, Daan, Antu, Helong, Longjing and Wangqing. As of the end of 2015, the rural poor population in the whole province was 711 thousand people [10]. At present, there are two contiguous poor areas and 8 national poverty counties in Jilin province. The income level of farmers in poverty-stricken areas is less than the provincial average level of $60 \%$. Two contiguous poor area concentrated on the $57 \%$ of the poor population in Jilin province, where has backward infrastructure, fragile ecological environment, poor production conditions and high cost of overcoming poverty.

In the early stage of the implementation of poverty alleviation strategy by Jilin provincial government, the poor people in rural areas showed the characteristics of regional concentration distribution. But with the impoverished population decreased year by year, this kind of special population showed the characteristics of dispersive distribution in the traditional poverty villages and counties, thus forming the distribution pattern of "dotted" in term of the rural poor population distribution. It means that not all farmers are poor in some poor township and there are also a certain number of poor people in non poor rural areas (shown in Table 1).

Table 1 Distribution of poverty areas in Jilin province

\begin{tabular}{l|l|c}
\hline Region & Poverty counties (cities) and its quantity & Proportion (\%) \\
\hline Eastern Alpine Region & $\begin{array}{l}\text { There are 4 key counties for poverty alleviation and } \\
\text { development, a total of 1469 poor villages in Tonghua } \\
\text { City, Baishan City, Yanbian Korea Autonomous } \\
\text { Prefecture and other 17 counties (cities). }\end{array}$ & $21.69 \%$ \\
\hline Central Plains Region & $\begin{array}{l}\text { There are 1315 poverty villages and 142.8 thousand } \\
\text { families in Changchun City, Jilin City, Siping City, } \\
\text { Liaoyuan City and other 15 counties (cities). }\end{array}$ & $4.00 \%$ \\
\hline $\begin{array}{l}\text { Western Arid Sandy } \\
\text { Region }\end{array}$ & $\begin{array}{l}\text { There are 3 key counties for poverty alleviation and } \\
\text { development and 1315 poverty villages in Baicheng } \\
\text { City, Songyuan City and other 8 counties (cities). }\end{array}$ & $15.98 \%$ \\
\hline
\end{tabular}

Source: Jilin Poverty Alleviation Office, 2012.

Note: "Proportion" refers to the proportion of rural poverty people in the local rural population.

Development Status of Pro-poor Tourism in Jilin Province. In recent years, Jilin provincial government combined poverty alleviation with rural tourism for developing local economy. By planning in advance, increasing investment and creating links, pro-poor tourism played a leading role in promoting the poor farmers to get rid of poverty.

In addition to give some policy support and some priority to these pilot villages for pro-poor tourism, Jilin provincial government has also selected some tourism planning and design institutes to make free project planning for these pilot villages in 2015. At the same time, the Provincial Tourism Bureau plays their own advantages, has invested 1.85 million yuan as the development funds for pro-poor tourism projects, focusing on promoting some projects, such as the blueberry picking experience garden project in Longdong village of Jingyu county, the Drama River Scenic Spots project in Antu county, the infrastructure construction projects in Chatiao village of Antu county, the folk culture tourism project in Longjing City and so on. These promote the development of tourism in poverty areas. Combined with the Provincial Development and Reform Commission, the Provincial Tourism Bureau help Dongqing 
county to construct the tourism infrastructure project. Provincial Development and Reform Commission and the Provincial Tourism Bureau work jointly to promote rural tourism poverty alleviation. They organized 8 key counties which are the national poverty alleviation and development counties to complete the declaration of "beautiful rural key village" in term of developing pro-poor tourism. There are 72 poor village be selected, and its rate of finalists is higher than the national average of $20 \%$. And the Provincial Tourism Bureau complete the establishment of archives work, identify 32 poverty stricken villages and help Tongyu, Antu and other counties to rank into the national tourism comprehensive reform pilots. In the process of developing pro-poor tourism, the Provincial Tourism Bureau selected 12 outstanding business units from the impoverished counties for improving the enthusiasm of rural tourism development in poor areas.

\section{Problems of Pro-poor Tourism Development in Jilin Province}

While affirming the effect of pro-poor tourism development, it also cannot ignore its constraints. The tourism industry insiders believe that the majority of local farmers lack the tourism service skills and the related knowledge of tourism reception, which has become a short board of rural tourism. In addition, due to the lack of policy incentives and supports, there is a certain degree of difficulty to attract local and foreign enterprises, social groups and other organizations to actively participate in poverty alleviation tourism.

Lack of Capital for Development of Pro-poor Tourism. Local governments lack of capital investment in term of pro-poor tourism. It mainly manifests in three aspects: firstly, due to financial difficulties, local governments lack of capital investment in the projects of pro-poor tourism; secondly, due to the region's economic backwardness and local people's low income, the local private capital accumulation is insufficient and the investment environment is poor, leading to the domestic and foreign capital investment enthusiasm is not high on pro-poor tourism; thirdly, tourism infrastructure is not complete. Tourism project needs long-term capital investment, while the period of cost recovery is longer. If there is no matching financial support, it is difficult to get the favor of credit funds.

Small Scale and Slow Development of Pro-poor Tourism in Jilin Province. At present, some tourism resources, which belongs to Baicheng in Jilin province, has formed a number of tourism products after a long period of development, and has a certain influence at home and abroad, such as the Xianghai National Nature Reserve. However, because the basis of the tourism industry in these areas is still relatively weak, and the development of tourism industry is unbalanced, the overall scale of the development has not yet reached the local GDP 5\%.

Less Kinds of Tourism Products for Poverty Alleviation. Most of the products are the primary products of tourism poverty alleviation, which is not enough to explore the cultural background and connotation of tourism resources. Because of the lack of development, it formed a relatively unitary tourism product about natural scenery and historical and cultural landscape. The development and marketing of tourist products are not in accordance with market demand, so the competitiveness of products are still relatively weak.

\section{Development Models of Pro-poor Tourism in Jilin Province}

The Independent Development Model of Local Interest Community. To increase income and obtain employment opportunities is the most important function of pro-poor tourism development. Many poverty-stricken areas in Jilin province can be leveraging on the periphery of tourist market, and take a path of independent development of local interest community for pro-poor tourism. Around the village committees can set up a association for pro-poor tourism, which can provide small financial support and some information consulting services. The village head is responsible for leading, and each household carry on independent operation and management, such as the development of sightseeing agriculture tourism, that can effectively promote the development of planting and breeding industry, and gradually forms tourism industry, can also provide a demonstration effect for poor neighborhoods. 
The Leading Model by Enterprises. From the perspective of regional industrial development, the development of tourism can play a leverage, which will package some quality tourism resources into tourism products, and then extend it into the related industrial chain. It is a process of long cycle, multi-input and wide chain, which needs a large number of foreign capital injection and be supported by perfect financial service system. The enterprises leading model is under the guidance of the government, relying on the rich tourism resources in Jilin Province, to establish the tourism companies or to attract strong investors and commercial banks to develop the local tourism business, and form a vibrant tourism industry gathering area, expanding and developing the tourism industry chain, so as to promote the development of local agriculture, trade and other related industries, to get rid of poverty and achieve the regional prosperity. The alpine region which is located in the east of Jilin province has good tourism resources, especially in the region of Changbai Mountain. It has become a leisure resort with many international and domestic brands. Therefore, the development of pro-poor tourism in the region of Tonghua, Baishan and Yanbian can get the benefit of cooperative development in international resort of Changbai Mountain, attracting some financial investment from some strong capital enterprises, accelerating the construction of leisure tourism, so as to achieve the goal of poverty alleviation.

The Driven Model of Policy Project. The driven model of policy project mainly refers to the local government and some international non-governmental organizations provide some policy projects in the poverty stricken areas in Jilin province, such as setting the tourism infrastructure funds, establishing the demonstration zone for pro-poor tourism and so on, to solve the employment problem for poverty population and increase the income for local poverty in Jilin province, and make the whole region to get rid of poverty.

The government plays an important role in the implementation of the effective PPT program. The government can do a lot of work in tourism planning, tourism infrastructure construction, tourism environmental governance, standardized management, project financing, program promotion, personnel training, etc.. In recent years, the Jilin Provincial Poverty Alleviation Office and Provincial Tourism Bureau attach great importance to the function of tourism industry in related work about poverty alleviation, support the development of the tourism industry in the poverty-stricken areas, and have some achievements.

\section{Conclusion}

The development pro-poor tourism has a long way to go in Jilin province. The efficiency of pro-poor tourism still has a great progress space in Jilin province. Including the independent development model of local interest community, the leading model by enterprises and the driven model of policy project, these development models which are proposed in this paper need to be further tested by practice. In the future, the research should consider some quantitative methods to measure the efficiency of pro-poor tourism.

\section{Acknowledgements}

This work was financially supported by Jilin Provincial Planning Office of Philosophy and Social Science Fund (No.2016B101) and the Research and Development Project of Jilin Engineering Normal University.

\section{References}

[1] B. Oliver and A. Caroline: Sustainable Tourism and Poverty Elimination Study: A Report to the Department for International Development (DFID, U.K. 1999).

[2] V.S. Foucat: Ocean \& Coastal Management, Vol. 45 (2002) No.8, p.511-529.

[3] Information on http://www.crctourism.com.au

[4] D. Schilcher: Current Issues in Tourism, Vol. 10 (2007) No.2, p.166-193. 
[5] S.L. Gao: Tourism Tribune, Vol. 12 (1997) No.4, p.8-10. (In Chinese)

[6] J.B. Tang: Journal of Chengdu University (Social Sciences), Vol. 27 (2007) No.2, p.71-75. (In Chinese)

[7] Y.P. Xiang and X.Y. Peng: Macroeconomic Management, Vol. 28 (2012) No.4, p.66-67. (In Chinese)

[8] L.M. Liu: Journal of Finance and Economics Theory, Vol. 19 (2012) No.1, p.75-79. (In Chinese)

[9] Y.L. Chen: Market Forum, Vol. 18 (2011) No.12, p.39-40. (In Chinese)

[10] Information on http://www.jl.gov.cn 